\title{
Efficient Market Hypothesis And Stock Market Anomalies: Empirical Evidence In Four European Countries
}

Matteo Rossi, University of Sannio, Italy

Ardi Gunardi, Universitas Pasundan, Indonesia

\begin{abstract}
The stock market efficiency is the idea that equity prices of listed companies reveal all the data regarding the company value (Fama, 1965). In this way, there isn't possible to make additional returns. However, evidence against the Efficient Market Hypothesis is growing. Researchers studied Calendar Anomalies (CAs) that characterised financial markets. These CAs contradict the efficient hypothesis. This research studies some of the most important market anomalies in France, Germany, Italy and Spain stock exchange indexes in the first decade of new millennium (20012010). In this study, to verify the distribution of the returns and their auto correlation, we use statistical methods: the GARCH model and the OLS regression. The analysis doesn't show strong proof of comprehensive Calendar Anomalies. Some of these effects are country-specific. Furthermore, these country-anomalies are instable in the first decade of new millennium, and this result demonstrates some doubt on the significance of CAs.
\end{abstract}

Keywords: EMH; Calendar Anomalies; January Effect; Weekdays Effect; France; Germany; Italy; Spain

\section{INTRODUCTION}

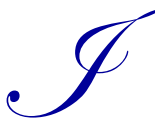
$\mathrm{n}$ the stock market an important principle used to measure the efficiency is the correlation between prices and all the information present in a market. The Efficient Market Hypothesis (EMH), also called Random Walk Theory (Kendall, 1953), is the consideration that the equity value of a listed firm reflects all data regarding the business value. "Efficient market" was presented in 1965 by Eugene Fama. He suggested that stocks always trade at fair value. This make impossible for investors to buy undervalued stocks or to sell stocks at overestimated prices. A market is efficient if prices adjust rapidly and, on average, without bias to new info. Thus, there isn't a reason to believe that prices are excessively high or low. So, in an efficient context it is impossible to beat the market. Investors pay a fair price. Based on this theory, an investor's only concern is selecting a particular riskreturns trade-off.

However, this model has received a significant amount of attention since its presentation. At first glance, it may be easy to identify a number of deficiencies in the efficient market theory. In fact, studies against the EMH are increasing, particularly with regard to return predictability (Rossi, 2016). Scholars who examine Calendar Anomalies (CAs) have indicated that CAs deny the stock market efficiency (Nasir, Khan and Rossi, 2016).

This study wants to examine calendar anomalies in four European markets. The paper has this structure: the second paragraph is a short literature review on calendar anomalies (or seasonal effects). In the third section, we explain the research method and the data collection. The empirical findings for the main CAs follow. The fifth section proposes explanations and conclusions regarding seasonal effects in the European stock markets.

\section{A LITERATURE REVIEW OF CAs}

In the past forty years, empirical checks have been realized to show the stock market efficiency. However, since the nineties, numerous studies have focused on examining the inefficiency of the markets by detecting various anomalies in the prices of the stock (Rossi, 2015). 
In this section, we describe the calendar anomalies in markets characterized by different micro-structures. Calendar anomalies are cyclic earnings irregularities in which the series is founded on the calendar. "The calendar time hypothesis states that the market behaves differently at different hours of the day, on different days of the week, and at various times of the month and year" (Rossi, 2015: 287). In general, the calendar effects studies form scholars are: (i) the month effect (in particular January), and (ii) the effected related to the weekdays.

\subsection{The January Effect}

"As goes January, so goes the year" is a popular rule in the equity market famous as the January effect. The earliest evidence of this seasonal effect was noted by Wachtel (1942). Rozeff and Kinney (1976) realize a research to thoroughly examine the anomaly in U.S. stock market. These researchers found anomalies in the monthly rates of NYSE return from 1904-1974: "With the exception of the 1929-1940 period, there are statistically significant differences in mean returns among months due primarily to large January returns" (Rozeff \& Kinney, 1976: 379). Gultekin and Gultekin 1983; Barone, 1990; Agrawal and Tandon, 1994 reported similar results. They showed atypical positive returns in other major developed nations. In particular, "Evidence is provided that there are strong seasonalities in the stock market return distributions... The seasonality, when it exists, appears to be caused by the disproportionately large January returns in most countries..." (Gultekin \& Gultekin, 1983: 469). Agrawal and Tandon (1994) found a January anomaly in eighteen countries other than the United States. Barone (1990) examined the Italian Stock Exchange (MIB) from 01/02/1975 to 08/31/1989: "The results obtained on the basis of the MIB index for the whole period considered show that the Italian stock market also has a pronounced seasonal pattern" (Barone, 1990:495). Banz, 1981; Roll, 1983; Keim, 1983 have examined the interaction between month-of-the-year and size effects. These studies found an important negative relationship between stock returns and the total market value of outstanding equity: "Evidence is provided that daily abnormal return distributions in January have large means relative to the remaining eleven months, and that the relation between abnormal returns and size is always negative and more pronounced in January than in any other month" (Keim, 1983: 13). Also, Fama (1991) studied the S\&P 500 performances during the period 1941-1981. He found that "the average monthly January return on a value-weighted portfolio of the smallest quintile of CRSP stocks is $8.06 \%$ (!), versus $1.34 \%$ for the S\&P 500" (1587). Brown et al., (1983) studied this seasonality in Australia, where the tax year ends on June 30. These researchers establish cyclic anomalies in December-January and July-August.

Wong, Agarwal, and Wonf (2006) investigate the CAs in the Singapore equity market (from 1993 to 2005): "Specifically, changes in stock index returns are examined surrounding January (the January effect), on different days of the week (the day-of-the-week effect), around the turn of the month (the turn-of-the-month effect) and before holidays (the pre-holiday effect)" (Wong et al, 2006: 123). Their results disclose that certain seasonalities have disappeared in Singapore in recent years, which "leads us to conclude that the January effect changes from positive in the pre-crisis to negative in the post-crisis period" (Wong et al., 2006: 128).

Mylonakis and Tserkezos (2008) examine the Athens Stock market (ASE) in the 1985-2001. They find that the mean returns during January are higher than in other months. The Baltic Stock Market seasonalities was studied by Norvaisiene, Stankeviciene and Lakstutiene (2015) They examine the "the daily log return indexes of Nasdaq OMX Tallinn, Nasdaq OMX Riga, and Nasdaq OMX Vilnius in Baltic stock exchange were analyzed for the period of 2003 - 2014" (Norvaisiene et al., 2015: 468). Their findings show that: "The research of the month effect in Baltic stock markets evidenced that January effect and October effect occurred in Estonia... The most successful months for investors in Lithuanian market were January, August and November as the stock return then was higher than in other months. Together with January, August and November effects, the October effect was established in Lithuania as seasonal trends of stock price decreases were observed in October" (Norvaisiene et al., 2015: 472-473).

\subsection{The Weekdays Effect}

Another important anomaly is the weekday effect. Typically, the U.S. market is characterized by low mean returns on the first day of the week in comparison with the other days of week. Osborne (1962) documented this CAs in the U.S. stock market. Later the weekdays effect was analysed by numerous researchers: Cross, 1973; French, 1980; Gibbons and Hess, 1981; Lakonishok and Levi, 1982; Keim and Stambaugh, 1984; Jaffe and Westerfield, 1985; Jaffe, Westerfield and Ma, 1989; Wang, Li and Erickson, 1997; Bildik, 2004. 
But, French (1980) and Jaffe et al. (1989) realized the most important studies on this topic. "They reported that average returns are significantly negative on Mondays and that these are significantly lower than the average returns for other weekdays in the USA. On the other hand, average returns on Friday are found to be positive and higher than average returns for the rest of the week" (Rossi, 2015: 289). "During most of the period studied, from 1953 through 1977, the daily returns to the Standard and Poor's composite portfolio are inconsistent... Although the average return for the other four days of the week was positive, the average for Monday was significantly negative..." (French, 1980: 55).

Jain and Joh (1988) showed that the exchanges volume of the NYSE in the first day of the week is about $90 \%$ of its usual volume from Tuesday to Friday. Wang et al. (1997), using data from 1962 to 1993 observe "that the well-known Monday effect occurs primarily in the last two weeks (fourth and fifth weeks) of the month. In addition, the mean Monday return of the first three weeks of the month is not significantly different from zero" (2171).

The weekdays anomalies were also analysed by Kiymaz and Berument (2003). They use the S\&P 500 index from 1972 to 1997: "The highest volatility occurs on Mondays for Germany and Japan, on Fridays for Canada and the United States, and on Thursdays for the United Kingdom," the researchers note (Kiymaz \& Berument, 2003: 363). Several researches shown that the anomaly may be linked to the fact that firms and governments tend to receive negative news over the weekend or that trading volumes increase on Fridays due to information symmetry and decrease on Mondays due to information asymmetry. Bildik (2004) affirmed that Monday anomaly vanish when "the returns of the final trading day of the previous week are positive" (Rossi, 2015: 290). Not all markets confirm the same deviations in the weekday effect. Jaffe and Westerfield (1985) study the daily returns of four equity markets. They discover that "lowest mean returns for the Japanese and Australian stock markets occur on Tuesday" (Jaffe and Westerfield, 1985: 433). Balaban (1995) detected a Tuesday effect in Turkey: "Empirical results verify that although day of the week effects are present in Istanbul Securities Exchange Composite Index (ISECI) return data for the period January 1988-August 1994, these effects change in direction and magnitude through time" (Balaban, 1995: 139).

\subsection{Other Calendar Effects}

Other types of calendar anomalies also have been examined by scholars. The effect linked to the turn-of-the-month (TOM), recognised by Ariel (1987) in the U.S. stock market, was followed by other studies: Pettengill and Jordan (1988), Lakonishok and Smidt (1988), Barone (1990), Agrawal and Tandon (1994), Hensel and Ziemba (1996), van der Sar (2003) and McConnell and Xu (2008). As noted by Rossi (2015: 291), other studies have examined the following CAs:

- The holiday effect (Lakonishok \& Smidt, 1988), also analysed by; Pettengill (1989), Ariel (1990), Barone (1990), Cadsby and Ratner (1992) and Dodd and Gakhovich (2011);

- The religious calendar effect, studied by Almudhaf (2012), Barmak (2012) and Nasir et al. (2016).

This brief analysis indicates a significant amount of fragmentation in the literature. "There is no single, unified point of view on the relationship of the EMH to calendar effects." (Rossi, 2015: 292).

\section{DATA AND METHODS}

This study aims to verify the January and the weekdays effects in the following four European countries: France, Germany, Italy and Spain. Using the Yahoo finance webpage, we collected daily data on these countries' equity market indexes from 01/02/2001 to 12/31/2010. In this study, we use the model previous tested from Borges (2009). So, dayto-day returns are calculated as follows:

$$
k n=\ln \left(\frac{P n}{P n}-1\right)
$$

In this formula $k n$ is the day-to-day return of the equity exchange index and $P n$ is the equity index at time $n$. 
So, all daily returns are calculated with an interval of one calendar day, except for the first day of the week: in this case we have a break of three calendar days. So, we have 2450 observations per country. In Table 1 there are descriptive statistics of the daily returns of the four stock markets.

Table 1. Descriptive Statistics for Daily Returns (2001-2010)

\begin{tabular}{l|c|c|c|c|c|c}
\hline Country & Observations & Mean & $\begin{array}{c}\text { Standard } \\
\text { Deviation }\end{array}$ & $\begin{array}{c}\text { Standard } \\
\text { Error of Mean }\end{array}$ & MAX & MIN \\
\hline France & 2461 & 0.0001716 & 0.0132970 & 0.0002263 & 0.07007 & -0.07683 \\
\hline Germany & 2463 & 0.0002947 & 0.0144467 & 0.0002450 & 0.07264 & -0.09432 \\
\hline Italy & 2441 & 0.0001894 & 0.0123344 & 0.0002089 & 0.06834 & -0.10639 \\
\hline Spain & 2435 & 0.0003311 & 0.0128988 & 0.0002211 & 0.06324 & -0.07343 \\
\hline
\end{tabular}

Source: Author's calculations

We discover that the mean daily returns range from $0.017 \%$ for the French market to $0.033 \%$ for the Spanish market. In this period, Germany has the maximum daily returns $(+7.26 \%)$, whereas the minimum daily returns occurred in Italy $(-10.63 \%)$. The Italian context is characterised for the lower standard error of the mean (0.0002089), suggesting lower return volatility, and higher in Germany $(0.0002450)$, a signal of relatively higher volatility.

This paper analyses the returns of stock exchanges, comparing the daily returns in specific periods. CAs could be analysed also by observing the returns of separate stocks of a specific country (French, 1980; Keim \& Stambaugh, 1984; Rogalski, 1984; Basher \& Sadorsky, 2006). Officer (1975) affirms: "Although the results indicate some evidence of a seasonal, it is shown that this is not prima facie evidence of market inefficiency. It is suggested that a more likely explanation is related to the structure of the economy, e.g., changing opportunity cost of money through the year" (Officer, 1975: 29).

For the stock exchange indexes, we accept the method usually adopted in the literature: we estimate five equations, each for a specific day. So, we've five different dummies, Di ( $i=1$ to 5 ).

$$
k n=a+\beta i D i n+\varepsilon n(1)
$$

In literature, the principal method for the stock exchange index is to estimate twelve different equations - from January to December - to detect the presence of a month effect. The approach is to consider twelve distinct dummies, Mi ( $\mathrm{i}=1$ to 12$)$ :

$$
k n=a+\beta i M i n+\varepsilon n(2)
$$

This general model, can be used to analyse any CAs.

Several studies on this topic (French, 1980; Gibbons \& Hess, 1981; Jaffe \& Westerfield, 1985) use the OLS regression. Connolly (1989) notes, however, that problems may rise with this method. First, the stock exchange index returns are expected to be auto correlated; in addition, the residuals are possibly non-normal, and the variance of the residuals may be variable (Borges, 2009).

For this reason, Engle (1982) propose the use of AutoRegressive Conditional Heteroscedasticity (ARCH) models: This is a way to correct variability in the residuals variance. These models assume that the variance of the residuals $\left(\sigma_{\mathrm{t}}^{2}\right)$ is not constant over time and that the error term cannot be shown $\varepsilon t \approx i i d\left(0, \sigma_{\mathrm{t}}^{2}\right)$. The common form of the GARCH model is realised by Bollerslev (1986). "The variance of the residuals is expressed as the sum of a moving-average polynomial of order q on past residuals (the ARCH term) plus an autoregressive polynomial of order $\mathrm{p}$, on past variances" (Borges, 2009: 13):

$$
\sigma_{t}^{2}=\alpha_{0}+\sum_{i=1}^{q} a_{i} \varepsilon_{t-i}^{2}+\sum_{I=1}^{p} \lambda_{i} \sigma_{t-1}^{2}
$$


Research aim is to detect calendar effects in two cases as follows:

a. effects related to different month, and

b. weekday effects.

\section{DATA ANALYSIS}

Using the previous discussed procedures, the analysis shows some important anomalies for all four stock exchange from 2001 to 2010 using Stata 14 software.

\subsection{OLS Regression}

The first step of my analysis was to compute specific OLS regressions for single country. To verify the presence of weekday effects we use model (1), and for the analysis of the month effects, we use model (2). The result was 20 regressions for the first effect analysed, and 48 regressions for the second effect. Assumed the non-normal distribution of the data, we use the OLS regressions calculated with robust standard errors (Table 2).

Table 2. Month Effects and Weekday effects (2001-2010): Differences in Mean Returns

\begin{tabular}{c|c|c|c|c}
\hline & France & Germany & Italy & Spain \\
\hline Month Effects & & & & $0.0012871^{*}$ \\
\hline 1 & 0.0004749 & 0.0008359 & -0.0001053 & $0.0008851^{*}$ \\
\hline 2 & -0.0003231 & $0.0012121^{*}$ & 0.0005649 & -0.0000444 \\
\hline 3 & 0.0005054 & -0.0001550 & 0.0009911 & -0.0006599 \\
\hline 4 & 0.0013473 & $0.0011499^{*}$ & $-0.0013156^{*}$ & -0.0008025 \\
\hline 5 & -0.0009063 & -0.0002721 & -0.0008788 & -0.0002298 \\
\hline 6 & -0.0002222 & -0.0002557 & -0.0001822 & -0.0009151 \\
\hline 7 & -0.0005472 & -0.0002311 & -0.0009034 & $-0.0012039^{* *}$ \\
\hline 8 & -0.0012451 & -0.0009988 & $-0.0012295^{*}$ & 0.0008933 \\
\hline 1 & $-0.0019366^{* *}$ & $-0.0014471^{* *}$ & -0.0001622 & 0.0007722 \\
\hline 11 & 0.0012451 & $-0.0009802^{*}$ & $0.00142591^{*}$ & 0.0006792 \\
\hline 12 & 0.0011559 & 0.0004971 & 0.0007922 & \\
\hline Weekday Effects & 0.0005599 & $0.0010654^{*}$ & & -0.0003911 \\
\hline 1 & & & -0.0005972 & -0.0000048 \\
\hline 3 & -0.0001959 & 0.0003257 & 0.0000211 & 0.0001423 \\
\hline 5 & 0.0001915 & -0.0000226 & -0.0003291 & -0.0001875 \\
\hline
\end{tabular}

*Significance level: $0.1 * *$ Significance level: $0.05 * * *$ Significance level 0.01

Source: Author's calculations

Numerous previous studies on calendar effects can be considered totally the consequence of data mining (Sullivan et al., 2001). For this reason, Cooper, McConnell and Octchinnikov (2006) "perform a randomized-bootstrap procedure to test the statistical significance of the indicator variable in the monthly time-series regressions" (322).

Also in this analysis, the results could be susceptible to the criticism: "Many researchers go to great lengths in attempts to avoid this pitfall. Ultimately, however, it has been extremely difficult for a researcher to account for the effects the cumulated "collective knowledge" of the investment community may have had on a particular study. The methods used here provide a principled way to conduct research as a sequential process in which new studies build on evidence from earlier papers" (Sullivan et al, 2001: 283). So, in the weekdays effects, the overall results do not differ significantly from those we might expect to find in a casually sample. With regard to the effect related to a specific month, we've six important coefficients (at 1\%), $9(5 \%)$ and $14(10 \%)$. These data are comparable to the number of significant coefficients we might suppose to discover with random data at 5\% (8) and 10\% (13). These results show a specific focus of the coefficients in specific part of the year and of a week. For these reasons, it will be possible further investigation. 
As first consideration, January has higher returns; however, this finding is only significant at $5 \%$ in two countries (Italy and Spain). A second reflection, for the four countries, daily returns are higher in four months for different reasons and with different significant level: April, October, November and December. In this last case, daily returns are higher only in one country. Third, all markets have poorer returns than average in August and September. The stronger month effect is clearly shown in September. If there weren't effects related to the months, the probability that in any month excess returns are negative is 0.5 . If we accept independence among the equity markets, the probability that all markets have negative excess returns in the same period is $0.5^{12}=0.024 \%$. In twelve months, the probability of obtaining this effect is: $0.024 \%$ x $12=0.288 \%$. However, because these stock markets are connected with each other, simultaneous activities in all markets are expected to occur. So, there isn't a proof of a month effect. The possible explanation is linked to the behaviour of investors (postponing investment decisions) related to summer holidays.

Although the specific coefficients for daily excess returns are not significant, there is a decrease in Monday, Tuesday and Wednesday in three countries, whereas we have positive returns on Thursdays and Fridays.

\subsection{GARCH Model}

To check the strength of the previous results, bootstrapping can be realized to the OLS regressions, as Sullivan et al. (2001) propose. After performing a test of ARCH effects on the data, we confirm that this is present in the data for all four markets. So, we re-estimate all models using the GARCH $(1,1)$ method. A lot of researches inferred that stock returns haven't a normal distribution and for that reason, we use - in this research - the Kruskal-Wallis test to verify whether the null hypothesis that all "clusters" come from the same population is valid. We choose to consider exclusively which weekday effects continue to be significant (at 5\%) for every of the statistical methods applied (Table $3)$.

Table 3. Weekday Effects by market

\begin{tabular}{l|c|c|c|c|c|c|c}
\hline \multicolumn{1}{c}{ Country } & \multicolumn{3}{c}{ Higher Returns } & \multicolumn{3}{c}{ Lower Returns } & $\begin{array}{c}\text { Kruskal - Wallis } \\
\text { Test }\end{array}$ \\
\hline & Regression & $\begin{array}{c}\text { Bootstrap/ } \\
\text { Regression }\end{array}$ & $\begin{array}{c}\text { GARCH } \\
\text { Model }\end{array}$ & Regression & $\begin{array}{c}\text { Bootstrap/ } \\
\text { Regression }\end{array}$ & $\begin{array}{c}\text { GARCH } \\
\text { Model }\end{array}$ \\
\hline France & - & Monday & - & - & - & - & 0.9453 \\
\hline Germany $^{*}$ & Tuesday $^{*}$ & Tuesday & Tuesday* $^{*}$ & - & - & - & 0.1190 \\
\hline Italy & - & Tuesday & - & - & - & - & 0.3033 \\
\hline Spain & - & - & - & - & - & - & 0.2679 \\
\hline
\end{tabular}

*Significance at the 0.05 level. **Significance at the 0.01 level.

Source: Author's calculations

Overall, the only country that indicates a stronger weekday effect is Germany, which shows high returns on Tuesdays. This result is consistent with the weekend effect widely previously recognised. But, the general results are: there isn't a weekend anomaly in the European stock markets.

As in the previous effect, we find no general month effects for all countries. Furthermore, the effects initially detected in certain countries (France and Italy) do not remain valid under more robust statistical methodologies (Table 4). Conversely, the stronger month effects include the following:

a. Germany has positive extra returns in February and negative returns in September;

b. Spain presents a positive excess returns in the January, and negative returns in May. 
Table 4. Month Effects by Country

\begin{tabular}{|c|c|c|c|c|c|c|c|}
\hline \multirow[t]{2}{*}{ Country } & \multicolumn{3}{|c|}{ Higher Returns } & \multicolumn{3}{|c|}{ Lower Returns } & \multirow[t]{2}{*}{$\begin{array}{c}\text { Kruskal - } \\
\text { Wallis Test }\end{array}$} \\
\hline & Regression & $\begin{array}{l}\text { Bootstrap/ } \\
\text { Regression }\end{array}$ & $\begin{array}{c}\text { GARCH } \\
\text { Model }\end{array}$ & Regression & $\begin{array}{l}\text { Bootstrap/ } \\
\text { Regression }\end{array}$ & $\begin{array}{c}\text { GARCH } \\
\text { Model }\end{array}$ & \\
\hline France & - & - & - & - & - & - & 0.4079 \\
\hline Germany & - & $\mathrm{Feb}^{*} / \mathrm{Apr}^{*}$ & $\mathrm{Feb}^{*}$ & Sep $^{*}$ & Sep $^{*}$ & Sep $^{* *}$ & $0.0385^{*}$ \\
\hline Italy & - & Apr/Jul ${ }^{*}$ & - & - & - & - & 0.0844 \\
\hline Spain & $\operatorname{Jan}^{* *}$ & $\operatorname{Jan}^{* *}$ & $\operatorname{Jan}^{* *}$ & Sep $^{*}$ & May $^{*}$ & May $^{*}$ & $0,0178^{*}$ \\
\hline
\end{tabular}

*Significance level $0.05 * *$ Significance level 0.01

Source: Author's calculations

The sample covers a period of ten years from 2001 to 2010. In addition, we examine whether the perceived CAs are constant during this period. This passage is important because the global results may be present in only a few of the years of the decade.

Furthermore, we compute regular window OLS regressions on the most significant coefficients detected in weekdays and monthly effects. We select four cases: (i) for positive day: Germany/Tuesday; (ii) for negative day: France/Monday; (iii) for positive month: Spain/January, and Italy/April; (iv) for negative month: Germany/September.

More specifically, in the German case, we verify that the coefficient comes positive in the 9th and 10th regression. In more than half the regressions, the upper bound on the $95 \%$ confidence interval is a positive return. In the Spanish case, the effect related to the first month appears to be linked primarily to the observations in the first years in the sample. Finally:

a. In France, the Monday anomaly appears to be a recent phenomenon, and

b. The April anomaly in Italy looks as a new effect.

These results confirm the high volatility of the CAs. For these reasons, in this stage there are strong doubts on the significance of the month and weekdays effects in the countries studied.

\section{CONCLUSIONS}

Numerous studies have documented on calendar anomalies principally in US stock markets. While international evidence of these effects continues to increase, studies have found mixed results. "The fragmentation of the literature on calendar anomalies has prevented the formulation of a general theory on this topic... there is no single, unified point of view on the relationship of the EMH to calendar effects" (Rossi, 2015: 293). Though progress has been made in understanding this theme, opportunities remain to improve the knowledge regarding the main motivations behind CAs. Furthermore, the heterogeneity of studies in CAs is linked to the topic investigated.

In this study, we apply a statistic method and we consider only those effects that are important under all different methods. The primary results include the following:

a. There isn't a strong evidence of an extensive calendar effect in the four nations examined. In particular, these countries appear to be generally protected to the effects related to a specific day. The only effect that requires further studies is the propensity for minor returns in September. In general, all the effects are specific for each country;

b. There is a similarity between number of significant coefficients that we detect and the number we would expect to discover randomly.

Although my analysis shows a concentration in a specific period, the results could be linked to a strong data mining. The confirmation is that we haven't calendar anomalies constant over time: sub-samples of the data show lower results. Thus, some calendar effects may haven't an economic basis, or they aren't linked to the market microstructure, but rather may be only a result of unpredictable movements in the four stock market considered.

For this reason, the study in the future could be addressed: 
- to consider a significant number of countries (not only four);

- to consider different calendar effects (not only January and weekday effects) for each country; and

- to consider recent years (2005-2015).

\section{ACKNOWLEDGEMENT}

Author's contribution - The article is the result of the common reflection of all the authors. In the editing phase, sections 1, 3, 4, 4.1, 4.2, 5 were written by Matteo Rossi, sections 2, 2.1, 2.2, 2.3 were written by Ardi Gunardi.

\section{AUTHOR BIOGRAPHIES}

Matteo Rossi is an Assistant Professor of Corporate Finance at the University of Sannio, Italy. He earned his $\mathrm{PhD}$ in Corporate Governance and his prime research interests are corporate finance, financial performances of SMEs, financing innovation and innovation systems. In all of these areas, he has published, contributed chapters to books, edited books and presented papers at national and international conferences. He is the Director for International Relations of the EuroMed Research Business Institute (EMRBI). In 2014, he won the Highly Commended Paper Award of the International Journal of Organisational Analysis (Emerald) for the paper 'Mergers and acquisitions in the high-tech industry: a literature review' and in 2012, he won the Outstanding Paper Award of the International Journal of Organisational Analysis (Emerald) for the paper 'Italian wine firms: strategic branding and wine performance.

Ardi Gunardi serves as a Lecturer associated with the Faculty of Economics and Business of Universitas Pasundan, Indonesia. His area of research interest and focus is corporate finance, governance, social responsibility, and financial literacy. He has publications in International Journal of Monetary Economics and Finance (Indexed in Scopus), International Journal of Economic Policy in Emerging Economies (Indexed in Scopus), International Journal of Energy Economics and Policy (Indexed in Scopus), Indian Journal of Economics and Development (Indexed in Thomson), among other scholarly outlets.

\section{REFERENCES}

Agrawal, A. \& Tandon, K. (1994). Anomalies or illusions? Evidence from stock markets in eighteen countries. Journal of International Money and Finance, 13(1), 83-106.

Almudhaf, F. (2012). The Islamic calendar effects: Evidence from twelve stock markets. International Research Journal of Finance and Economics, 87.

Ariel, R. (1987). The monthly effect in stock returns. Journal of Financial Economics, 18(2), 161-174.

Ariel, R. A. (1990). High stock returns before holidays: Existence and evidence on possible causes. The Journal of Finance, 45(5), 1611-1626.

Balaban, E. (1995). Day of the week effects: New evidence from an emerging market. Applied Economics Letters, 2, $139-143$.

Banz, R. W. (1981). The relationship between return and market value of common stocks. Journal of Financial Economics, 9, 318.

Barmak, S. (2012). The Ramadan effect. Canadian Business, 85(14), 62-63.

Barone, E. (1990). The Italian Stock Market: Efficiency and calendar anomalies. Journal of Banking \& Finance, 14(2-3), 483510.

Basher S. \& Sadorsky P. (2006). Day-of-the-week effects in emerging stock markets. Applied Economics Letters, 13(10), 621628.

Bildik, R. (2004). Are Calendar Anomalies Still Alive? Evidence from Istanbul Stock Exchange, Istanbul Stock Exchange, Working Paper Series, available at SSRN: http://ssrn.com/abstract=598904

Bollerslev, T. (1986). Generalized Autoregressive Conditional Heteroskedasticity, Journal of Econometrics, 31, (3, 307-327

Borges M. R. (2009). Calendar Effects in Stock Markets: Critique of Previous Methodologies and Recent Evidence in European Countries, WORKING PAPERS, School of Economics and Management - TECHNICAL UNIVERSITY OF LISBON, available at http://www.repository.utl.pt/bitstream/10400.5/1825/1/getFile37.pdf, Accessed 28 February 2017

Brown, P., Keim, D. B., Keleidon, A.W..., \& Marsh, T. A. (1983). Stock return seasonalities and the tax-loss-selling-hypothesis: Analysis of the arguments and Australian evidence. Journal of Financial Economics, 12(6), 105-127.

Cadsby, C. B. \& Ratner, M. (1992). Turn-of-the-month and pre-holiday effects on stock returns: Some international evidence, Journal of Banking and Finance, 16,(3), 497-509. 
Connolly, R. (1989). An examination of the robustness of the weekend effect. Journal of Financial and Quantitative Analysis, $24,133-170$.

Cooper, M., J. McConnell \& Octchinnikov A. (2006). The other January effect. Journal of Financial Economics, 82(3), $315-341$.

Cross, F. (1973). The behavior of stock prices on Fridays and Mondays. Financial Analysts Journal, 29, 67-69.

Dodd, O. \& Gakhovich, A. (2011). The holiday effect in Central and Eastern European financial markets. Investment Management and Financial Innovations, 8(4), 29-35.

Engle, R. F. (1982). Autoregressive conditional heteroscedasticity with estimate of the variance of United Kingdom inflation. Econometrica, 50(4), 987-1008

Fama, E. F. (1991). Efficient Capital Markets: II. The Journal of Finance, XLVI(5), 1575-1617.

Fama, E. F. (1965). Random Walks in Stock Market Prices. Financial Analysts Journal, 21(5), 55-59.

French, K. R. (1980). Stock returns and the weekend effect. Journal of Financial Economics, 8, 55-70.

Gibbons, M. \& Hess, P. (1981). Day of the week effects and asset returns. Journal of Business, 54, 579-96.

Gultekin, M. N. \& Gultekin, N. B. (1983). Stock Market Seasonality. International Evidence. Journal of Financial Economics, 12(4), 469-481.

Hensel, C. R. \& Ziemba, W. T. (1996). Investment results from exploiting turn-of-the-month effects. (Digest Summary). Journal of Portfolio Management, 22 (3), 17-23

Jaffe, J. \& Westerfield, R. (1985). The weekend effect in common stock returns: The international evidence. Journal of Finance, 40, 237-44.

Jaffe, J. F., Westerfield, R. \& Ma, C. (1989). A twist on the Monday effect in stock prices: Evidence from the US and foreign stock markets. Journal of Banking and Finance, 13(4-5), 641-650.

Jain, P. C. \& Joh, C. H. (1988). The dependence between hourly prices and trading volume. Journal of Financial and Quantitative Analysis, 23(3), 269-284.

Keim, D. B. (1983). Size related anomalies and stock return seasonality: Further empirical evidence. Journal of Financial Economics, March, 13-32

Keim, D. B. \& Stambaugh, R. F. (1984) A further investigation of the weekend effect in stock returns. Journal of Finance, 39(3), 819-835.

Kendall, M. G. (1953). The analysis of Economic Time Series, Part I. Prices. Journal of the Royal Statistical Society, 96, 11-25.

Kiymaz, H. \& Berument, H. (2003). The day of the week effect on stock market volatility and volume: International evidence. Review of Financial Economics, 12, $363-380$

Lakonishok, J., \& Levi, M. (1982). Weekend effect in stock return: A note. Journal of Finance, 37, 883-889.

Lakonishok, J. \& Maberly, E. (1990). The weekend effect: Trading patterns of individual and institutional investors. The Journal of Finance, 45, 231-243.

Lakonishok, J. \& Smidt, S. (1988). Are seasonal anomalies real? A ninety-year perspective. The Review of Financial Studies, 1(4), 403-425

McConnell, J. J. \& Xu, W. (2008). Equity returns at the turn of the month. Financial Analysts Journal, 64(2), 49-64.

Mylonakis, J. \& Tserkezos, D. (2008). The January effect results in the Athens Stock Exchange (ASE). Global Journal of Finance and Banking Issues, 2(2), 44-55.

Nasir, M.A., Khan, K. \& Rossi M. (2016). The calendar anomalies on performance and volatility of stock market: The effects of Ramadan on Karachi Stock Exchange. Global Business and Economics Review (forthcoming).

Norvaisiene, R., Stankeviciene, J. \& Lakstutiene, A. (2015). Seasonality in the Baltic Stock Markets. Procedia - Social and Behavioral Sciences, 213, 468-473.

Officer, R., (1975). Seasonality in Australian capital markets: Market efficiency and empirical issues. Journal of Financial Economics, 2, 29-51.

Osborne, M. F. M. (1962). Periodic structure in the Brownian motion of stock returns. Operations Research, 10, $345-379$.

Pettengill, G. N. (1989). Holiday closings and security returns. The Journal of Financial Research, 12(1), 57-67.

Penntengill, G. N. \& Jordan, B. D. (1988). A Comprehensive Examination of Volume Effects and Seasonality in Daily Security Returns. Journal of Financial Research, 11 (1), 57-70.

Rogalski, R. J. (1984). New findings regarding day-of-the-week returns over trading and non-trading periods: A note. Journal of Finance, 39, 1603-14.

Roll, R. (1983). Vas ist das? The turn of the year effect and the return premium of small firms. Journal of Portfolio Management, 9(1), 18-28.

Rossi, M. (2015). The efficient market hypothesis and calendar anomalies: A literature review. International Journal of Managerial and Financial Accounting, 7(3-4).

Rossi, M. (2016). The Capital Asset Pricing Model: A critical literature review. Global Business and Economics Review, 18(5), 604-617.

Rozeff, M. S. \& Kinney Jr., W. R. (1976). Capital market seasonality: The case of stock returns. Journal of Financial Economics, 3(4), 379-402.

Steeley, J. M. (2001). A note on information seasonality and the disappearance of the weekend effect in the UK stock market. Journal of Banking and Finance, 25, 1941-1956. 
Sullivan, R., Timmermann, A. \& White, H. (2001). Dangers of data mining: The case of calendar effects in stock returns. Journal of Econometrics, 105(1), 249-286.

van der Sar, N. (2003). Calendar effects on the Amsterdam Stock Exchange. De economist, 151(3), 271-292.

Wachtel, S. B. (1942). Certain observations on seasonal movement in stock prices. Journal of Business, 15(1), 184-193.

Wang, K., Y. Li, \& Erickson, J. (1997). A new look at the Monday effect. Journal of Finance, 52, 2171-2186.

Wong W. K., Agarwal A., Wonf, N. T. (2006). The disappearing calendar anomalies in the Singapore Stock Market. The Lahore Journal of Economics, 11(2), 123-139 Wing-Keung. 